\title{
First report of powdery mildew caused by Podosphaera astericola on Kalimeris incisa in Korea
}

\author{
In-Young Choi ${ }^{1} \cdot$ Chong-Kyu Lee ${ }^{2} \cdot$ Hyeon-Dong $\operatorname{Shin}^{3}$ (D)
}

Received: 17 April 2021 / Accepted: 1 October 2021 / Published online: 15 October 2021

(c) Società Italiana di Patologia Vegetale (S.I.Pa.V.) 2021

Keywords Aster incisus $\cdot$ Japanese aster $\cdot$ Native species

In October 2020, Kalimeris incisa (Fisch.) DC. (syn. Aster incisus Fisch.) plants showing symptoms of powdery mildew were observed in the natural habitats of Wonju and Seoul, Korea (50\% disease incidence). Thinly effuse or powdery white colonies were observed on leaves and stems. Conidiophores were upright from creeping hyphae, 120-240 $\times$ $10-12 \mu \mathrm{m}$ and formed apically 2 to 4 immature catenate conidia. Conidia were ellipsoid-ovoid to barrel-shaped, $26-38 \times 18-22 \mu \mathrm{m}$, and containing distinct fibrosin bodies. Chasmothecia of the fungus were not observed. For further studies, rDNA was extract from two reference specimens (KUS-F32067 and F32098; Korea University Herbarium). The PCR amplification was performed with ITS1F and PM6 primers for internal transcribed spacer (ITS) and PM3 (Takamatsu and Kano 2001) and TW14 primers for the large subunits (LSU). The resulting ITS and LSU sequences were enrolled in GenBank (Accession os. MW931848, MW931849 for ITS; MW931852, MW931853 for LSU). A BLASTn search showed high sequence similarities (>99.6\%) with Podosphaera astericola U. Braun \& S. Takam. on Aster spathulifolius (MF476989) for ITS and on Aster microcephalus var. ovatus (AB462779) for LSU. Morphological characteristics and molecular sequence analysis were consistent with those of P. astericola (Braun and Cook 2012). Pathogenicity was confirmed by dusting conidia onto leaves of three healthy $K$. incisa plants. Three non-inoculated

Hyeon-Dong Shin

hdshin@korea.ac.kr

1 Department of Agricultural Biology and Department of Agricultural Convergence Technology, Jeonbuk National University, Jeonju 54896, Korea

2 Department of Forest Resources, Gyeongsang National University, Jinju 52725, Korea

3 Division of Environmental Science and Ecological Engineering, Korea University, Seoul 02841, Korea plants served as controls. Ten days after inoculation, inoculated plants developed mycelial patches, whereas the controls remained healthy. Although many cases of Aster (Kalimeris)-Podosphaera association have been reported, this is the first report of P. astericola on K. incisa in Korea and worldwide (Farr and Rossman 2021). Several commercial cultivars of $K$. incisa are sold in flower markets. Therefore, this finding has broad importance for both floriculture business and the ecological conservation of native species.

Acknowledgements This work was supported by Korea Institute of Planning and Evaluation for Technology in Food, Agriculture and Forestry (IPET) through Crop Viruses and Pests Response Industry Technology Development Program, funded by Ministry of Agriculture, Food and Rural Affairs (MAFRA) (Project No. 320043-05).

\section{Declarations}

Informed consent The manuscript is new and not being considered elsewhere. All authors have approved the submission of this manuscript.

Conflict of interest The authors have no conflict of interest to declare.

\section{References}

Braun U, Cook RTA (2012) Taxonomic manual of the Erysiphales (Powdery Mildews), CBS Biodiversity Series No. 11. CBS, Utrecht, Netherlands

Farr DF, Rossman AY (2021) Fungal databases, syst. Microbiol. Lab., Online publication. ARS, USDA, Mycol

Takamatsu S, Kano Y (2001) PCR primers useful for nucleotide sequencing of rDNA of the powdery mildew fungi. Mycoscience 42:135-139

Publisher's Note Springer Nature remains neutral with regard to jurisdictional claims in published maps and institutional affiliations. 